\title{
Global subsiding as a way to sustainable fishery
}

\author{
Viktoria Dorofeeva* , Elena Klippenstein, and Dmitry Kuznetsov
}

Kaliningrad State Technical University, Sovetsky ave., 1, 236022 Kaliningrad, Russia

\begin{abstract}
Government subsidies affect many kinds of world's fishery and are intended to restore troubled fisheries. The article shows that current information about global subsidies for fishery are fragmentary due to lack of its classification and accounting. But at the same time, many fishery countries allow overfishing, illegal, unreported and unregulated fishing. As a result, bioresources are overexploited, and economical indicators of fishing deteriorate. Depleted reserves of fish in seas, and also economical and social problems within fishery society is a result of exploiting of marine bioresources in terms of lack of proper fishing management system. We have made an attempt to summarize approaches of different organizations to classify global subsidies. The presented analysis shows that the largest share of subsidies falls on fuel, which is undoubtable a negative tendency. The assessment of subsidies level for the largest fishery countries is implemented. Scientific and practical recommendations are formulated, its compliance may provide the growth of economical state without accelerating the depletion of fish stocks.
\end{abstract}

\section{Introduction}

The Code of Conduct for Responsible Fisheries [FAO,1995] established "sustainability" as a fundamental principle in fishery management, stating that "the long term sustainable use of marine fishery bioresources is main purpose of conservation and management". Sustainable fishing is a process that provides the long term compromise between social and economical goals of fishery and objectives of protecting and conserving exploited resources at the population and ecosystem levels. At the same time, species diversity and sustainable functioning of the exploited ecosystem and the level that meets the social and economical interests of fisheries.

Fishing and catch processing, united in a system of fishery branches are socially significant and important elements of economical mechanism of the most countries. Fishery is important for both coastal and landlocked countries, as all of them are involved in relationships of production or exchange of fish products.

It is also important to account the significance of fish products in human nutrition. According to FAO data, more that 90 million tons of fish are caught annulay in the World ocean, and more that 60 million tons are caught in aquaculture farms. Today, the average

* Corresponding author: $\underline{\mathrm{d} 310574 @ \text { yandex.ru }}$ 
inhabitant of the planet consumes 19.2 kilograms of fish yeayrly, and in 60 s this number was only 9.9 killograms [1].

Government support of fishery complex is implemented with varying degrees of intensity for many decades. But at the same time, directions, methods, forms and volume of such support often create disputes, called "fish wars". Thi is due to interest of all countries in existing of certain "game rules", because all exploited resources are reproducible and belong to the whole humanity.

Although current information about subsidies to fishery is often undetermined and fragmentary, it is necessary to have a clear understanding of volume of subsidies and their probable influence on industry competitiveness and state of the ecosystem.

\section{Materials and methods}

Purprose of the research is to investigate current level of subsidization of the world fishery sector and develop the range of scientific and practical recommendations to increase the level of sustainable development of fishing in terms of its global subsidization.

Subsidies to fishery artificially increase profits by reducing the cost of fishing and/or increasing the income of fishermen, leading to overcapacity and overfishing. Subsidies to fishery is a "financial contribution" of government or any government agency that makes profit to private sector through transfers of funds, including grants, loans, and capital injections, or potential transfers, of funds such as loan guarantees,; lost government revenues from tax breaks; goods and services provided to the private sector, except general infrastructure; indirect support through government payments for finance mechanism; any form of income or price support. They belong to industrial subsidies, so the mechanism, terms and order of its presentation have not been included in Uruguay Round Agreement on agriculture GATT [2]. It predetermined a certain ambiguity in approaches for forming the regulatory environment in fishery. Firstly, fishing is classified as an agri-food sector at national level in many countries, secondly, close relations between problems of fishing regulation at global level and food security, sustainable development, environmental stability involve different sectors of society, which are not directly related to the production and trade of fish products in the discussion process [2]. Thus, the problem of fishery subsidization in last decade has gone far beyond the realization of industrial and trade policies.

Repeatedly on the sidelines of many international conferences and forums, there were many calls to ban global subsidies, the use of which leads to additional power increase of the fishing fleet and, accordingly, to overfishing of the biological resources in the World ocean [3]. BTO first officially recognized the need to reform subsidies to fishery in 2001. Negotiation have intensified after the UN presented set of Sustainable Development Goals (SDG). It includes SDG 14.6 that calls for a ban of subsidies, promoting overfishing, and an end to illegal, unreported and unregulated fishing [4]. Nevertheless, the issue of feasibility of maintaining subsidies in fishery is still actively discussed.

Results of the research have shown that during the process of discussing fishery subsidies there are uncertainty and imprecision. This is due to the fact that different researches and programs do not have unified classification approaches to classifying and government transfers, support programs, economical support etc. Thus, today there is no generally accepted classification of subsidies [4-10]. So, it seems appropriate to generalizae some approaches to the classification, indicating used features of classification (Table 1).

Table 1. Approaches to grading grants used by different organizations/programs.

\begin{tabular}{|c|c|}
\hline Organization / program & $\begin{array}{c}\text { Used features of subsidies } \\
\text { classification }\end{array}$ \\
\hline
\end{tabular}


Table 1. Continued.

\begin{tabular}{|l|l|}
\hline WTO (1994) & Receivers, trade impact \\
\hline The World Bank (1998) & $\begin{array}{l}\text { Measuring economical } \\
\text { impact }\end{array}$ \\
\hline APEC (2000) & Use of subsidies, their scope \\
\hline FAO (2002) & $\begin{array}{l}\text { Transfer types, economical } \\
\text { impact of subsidies }\end{array}$ \\
\hline UNEP (2004) & Goals of subsidization \\
\hline OECD (2020) & Receivers \\
\hline $\begin{array}{l}\text { European commision } \\
\text { (2020) }\end{array}$ & Impact on fishery resources \\
\hline
\end{tabular}

* Resource: compiled by the author based on [2, 4-10].

Based on the results of the analysis, it becomes clear to understand that current scientific and practical approaches, which would contribute to streamlining the accounting and assessment of subsidies, aimed at the development of fishery power are extremely need in improvement.

\section{Results and discussion}

In modern conditions, it is necessary to explore latest scientific data about subsidization in chosen branch. Some analytics claim that subsidies make fishery more profitable than it is in reality, while other say that subsidies lead to global reduce of fish population.

During the latest and comprehensive research of subsidies to fishery, the international group of scientists have revealed that 35 billion dollars of the USA public funds were spent on fishery subsidies in 2020. 22 billions of them were classified as harmful, because they were directed to increase the capacity of catch, not to increase potential and competitiveness of the fish industry, which is undoubtable an alarming tendency [11].

Data, that have been published in Marine Policy magazine, point that fuel subsidies account for almost a quarter (22\%) of all financial support, provided to fishing fleets [12]. Fuel subsidies are some of the most harmful and least justified as they allow more ships to spend at sea the time, which is necessary for pursuing disappearing fish population. Besides, categorization of tax-free fuel as subsidies is controversial due to the different approach to this issue if different countries [13].

The conducted theoretical generalization of data, which is presented in $[2,3,11,12]$ has allowed us to group global subsidies into 12 categories, which include management, researches, construction and technological works, fleet modernization, development projects, ports and berths, marketing and storage of products, tax incentives, access to fish resources, fuel subsidies, support of fishermen, redemption of ships and assisting to fishing farms (Picture 1). 


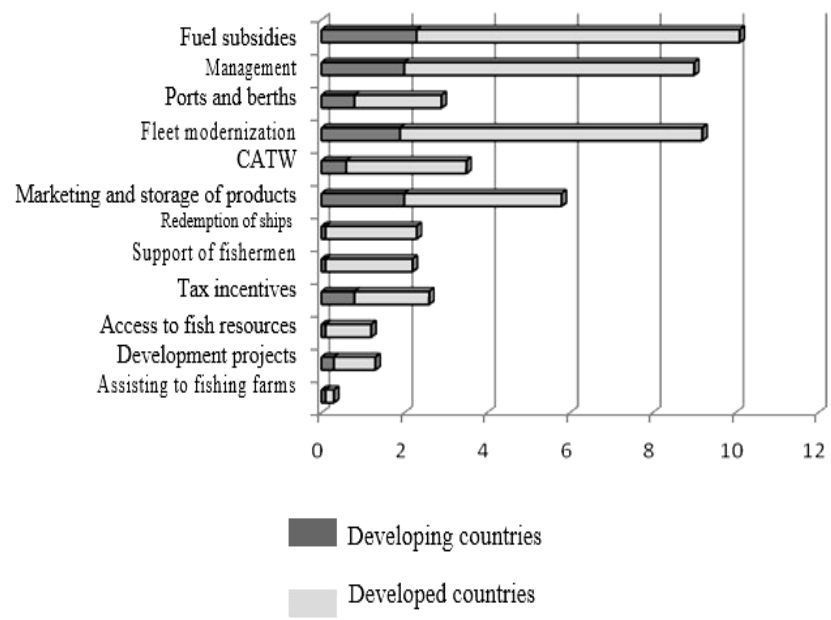

Fig. 1. Distribution of global subsidies by category, USD billion.

During the research we have revealed, that subsidies, which increase power, prevails those, which increase benefits from activity, and ambiguous subsidies. This situation remains both in developing and developed countries. More than $80 \%$ of all subsidies fall in the subsector of large (industrial) fishing. Developed countries get most of world subsidies. It is obvious that most of the small-scale fishing fleet belongs to developing countries. So, we may conclude that the small-scale fishermen get less subsidies than those, working in large-scale fisheries.

In the total mass, the share of subsidies for management is about $20 \%$, and for development of ports and berths - 10\%. Subsidies in developed countries (65\%) significantly prevail their number in developing countries (35\%). Subsidies for fishing play an important role in China, Taiwan, the USA and South Corea, while subsidies for fsih farming and raising are highest in Russia and China. The largest subsidies aimed to researches, infrastructure, fuel (China) and insurance (Japan) [14].

Asia dominates in field of subsidies, provided to marine fisheries. Asia accounts for $55 \%$ of the global total, followed by Europe (18\%) and North America (13\%). However, China accounts for $21 \%$ of global subsidy payments, followed by the USA (10\%) and Korea (9\%) [15].

It should be noted, that those numbers show absolutely different approaches and actions. While subsidies from the USA government, as a rule, bring benefits, Korean, Russian and Chinese subsidies are generally classified as harmful [16]. According to certain fishery subsides analysis, published by the World institute of environment and development, China has the world's largest fishing fleet, accounting more than 270000 ships, and an annual catch is 18 million tons. [17]. It dwarfs 5 million tons offloaded by Europe, 4 million by Russia and 4 million by the USA. At the same time, China provides record subsidization (7,5 billion USD in 2020), but notes that it plans to reduce amount of its foreign fleet. Fuel subsidization in china may really be changed in future, as the country's thirteenth Five-year plan stated that the purpose of the country is to "regularly reduce subsidies for diesel fuel ..." [18].

Japan and the European Union provide their fleets with over 2 billion USD capacity expansion subsidies [19]. Subsidies, that they still provide, exacerbate overfishing in foreign waters and in open sea. Meanwhile, as responsible global partners, recognizing that their subsides are a catalyst for overfishing outside their own economical zones [20], they 
should take the responsibility and become the world's leaders in subsidies discipline for increasing its potential.

During the research, we have made a conclusion, that it is necessary to liquidate the subsidies, which contribute to overuse of the ecosystem. One of the solutions is a careful analysis of influence of fishery subsidies, renegotiation of the fishery management agreement and discussion of food sufficiency issue.

Over the past decade, there is a slight reduce of subsidies, which is encouraging. However, most of the subsidies for opportunities expansion are still active [21, 22]. Nevertheless, it is necessary and possible to cancel subsidies for increase of production power or at least redirect them to benefit billions of people, which nutrition and livelihoods depend on seafood.

\section{Conclusions}

Subsidization should become a mechanism, which provides sustainable development of fishery. Taking it into account, all fishery countries should think about aftermaths of their actions related to environment. Ultimately, policymakers should find smart ways to increase economical wealth, without accelerating of attrition of fish stocks. For this, from our point of view, in the near future it is necessary to:

- adopt a uniform approach for classification of global subsidies;

- reduce or stop providing subsidies aimed to increase of power, as they the intensively lower fish stocks;

- increase subsidies, which expand activity benefits, in particular, financial support during collection of data, control organization, and those that improve management of fisheries by reducing fishing powers;

- improve the transparency of reporting on the use of subsidies, introduce efficient reporting on subsidies in terms of BTO;

- improve the transparency in accounting reports of industrial companies, regarding the justification of necessity of getting subsidies;

- take into account special interest of developing countries and small scale fishery, which need help and do not harm the resource base;

— increase monitoring of influence of such subsidies on fishery to determine which subsidies bring, ore benefits;

- to transfer subsidies aimed at power increase for support of sustainable activity. It will contribute to improvement of fishermen activity by provided subsidies, and resource base will rest from sheep fishery.

\section{References}

1. The State of World Fisheries and Aquaculture (2018)

2. U. R. Sumaila, A. S. Khan, A. J. Dyck, R. A. Watson, G. R. Munro, P. H. Tyedmers, D. J. Pauly, J. Bioec., 12 (2014)

3. U. R. Sumaila, D. Pauly, Fish. Cent. Res. Rep., 14 (2006)

4. WTO, Agreement on Subsidies and Countervailing Measures. https://www.wto.org/

5. World Bank, Vulnerable Group Feeding, http://documents.worldbank.org/

6. WTO, Subsidies and Countervailing Measures, https://www.wto.org/

7. EMFF - Country Files, https://ec.europa.eu/ 
8. APEC Study into the Nature and Extent of Subsidies in the Fisheries Sector of APEC Member Economies (2000)

9. J. A. Anticamara, R. Watson, A. Gelchu, D. Pauly, Fish. Res., 107 (2011)

10. U. R. Sumaila, V. Lam, F. Le Manach, W. Swartz, D. Pauly, Mar. Policy, 69 (2016)

11. Y. Sakai, N. Yagi, U. R. Sumaila, Fish. Sci., 85 (2019)

12. U. R. Sumaila, N. Ebrahim, A. Schuhbauer, D. Skerritt, Y. Li, H. S. Kim, T. G. Mallory, V. W. Lam, D. Pauly, Mar. Policy, 109 (2019)

13. Subsidies: a way towards a sustainable fisheries? (2005)

14. M. Milazzo, Subsidies in World Fisheries: A Re-examination (1998)

15. R. A. Watson, W. W. L. Cheung, J. A. Anticamara, U. R. Sumaila, D. Zeller, D. Pauly, Fish and Fish., 14 (2013)

16. N. M. Vdovenko, Econ. And Man. Of Nat. Econ. 5(6) (2015)

17. U. R. Sumaila, A. S. Khan, A. J. Dyck, R. Watson, G. Munro, P. Tydemers, D. Pauly, J. Bioecon., 12 (2010)

18. U. R. Sumaila, S. Villasante, F. Le Manach, Nature, 571 (2019)

19. M. D. Smith, Science, 364 (2019)

20. A. McCrea-Strub, D. Zeller, U.R. Sumaila, J. Nelson, A. Balmford, D. Pauly, Mar. Policy, 35 (2011)

21. U. R. Sumaila, T. C. Tai, V. W. Lam, W. W. Cheung, M. Bailey, A. M. CisnerosMontemayor, O. L. Chen, S. S. Gulati, Sci. Adv., 5 (2019)

22. E. Sala, J. Mayorga, C. Costello, D. Kroodsma, M. L. Palomares, D. Pauly, U. R. Sumaila, D. Zeller, Sci. Adv., 4 (2018) 